\title{
Growth inhibition by metformin in YD-38 oral cancer cells derived from Korean
}

\author{
Dong Kuk Seo, Su-Gwan Kim, Dae-San Go, Chun Sung Kim, Sun-Kyoung Yu, and Do Kyung Kim* \\ Oral Biology Research Institute, School of Dentistry, Chosun University, Gwangju 61452, Republic of Korea \\ (Received Mar 27, 2017; Accepted May 22, 2017)
}

\begin{abstract}
Metformin (1,1-dimethylbiguanide hydrochloride), derived from French lilac (Galega officinalis), is a first-line drug prescribed for patients with type 2 diabetes. It has been reported to have anti-cancer effects in a variety of cancer cells. However, effects of metformin on oral cancer cells have not been clearly established. The main goal of this study was to investigate the effect of metformin on cell growth and apoptosis induction in oral cancer cells derived from Korean patients. The effect of metformin on cell growth and apoptosis induction in oral cancer cells was examined by inhibition of cell growth, DNA fragmentation analysis and immunoblotting in YD-38 human oral cancer cells derived from Korean patients. Treatment with metformin induced inhibition of cell growth depending on the metformin treatment time and concentration in YD-38 human oral cancer cells. Treatment with metformin induced nuclear fragmentation in YD-38 human oral cancer cells. Metformin promoted proteolytic cleavage of procaspase- 3 with an increase in the amount of cleaved caspase-3. Cleaved PARP was increased by metformin in YD-38 human oral cancer cells. Treatment of YD-38 human oral cancer cells with metformin increased the level of Bax, but it decreased the level of Bcl-2. These results suggest that metformin can induce suppression of cell growth and cell apoptosis in YD-38 human oral cancer cells derived from Korean patients.
\end{abstract}

KEY WORDS: Apoptosis, Cell death, Metformin, Oral cancer cells

\section{Introduction}

Metformin (1,1-dimethylbiguanide hydrochloride), derived from French lilac (Galega officinalis), is one of anti-diabetic drugs that belongs to the biguanide class, and a firstline drug prescribed for patients with type 2 diabetes [1-3]. It exerts its anti-diabetic effect by reducing hepatic glucose production $[4,5]$. Moreover, it is known to mimic the condition of nutrient starvation by blocking the electron transport chain complex I in mitochondria, and reducing the ATP/AMP ratio [6-8]. In addition, metformin is known to used in the treatment of polycystic ovarian syndrome [9] or non-alcoholic fatty liver disease [10]. Recently, metformin has been reported to have anti-cancer effects in

*Corresponding author: Do Kyung Kim

Department of Oral Physiology, School of Dentistry, Chosun University, 309 Pilmun-daero, Dong-gu, Gwangju 61452, Republic of Korea Tel.: +82-62-230-6893, Fax: +82-62-232-6896

E-mail: kdk@chosun.ac.kr colon cancer, ovarian cancer, lung cancer, breast cancer and prostate cancer and so on [11-16]. Although it was shown to reduce the cancer cell viability, its action mechanisms remain to be determined. In addition, the effects of metformin on oral cancer are unclear.

Oral cancer is a major worldwide public health problem that may modify any part of the oral cavity, including the lips, tongue, mouth and throat [17-19]. Despite the introduction of novel therapeutic modalities to treat oral cancer, improvements in the long-term survival rates have been modest [20]. Therefore, multi-clinical studies, including surgical excision, radiation therapy and chemotherapy, have been designed and performed to help find the novel method for treating oral cancer [17, 20, 21]. And also, although the oral cancer research has made progress to date, the molecular mechanism underlying oral cancer is not understood yet.

The present study, therefore, examined the effects of metformin on cell growth and the mechanism of cell death elicited by metformin in YD-38 human oral cancer cells 
Dong Kuk Seo et al.

derived from Korean.

\section{Materials and Methods}

\section{Materials}

Metformin (1,1-dimethylbiguanide hydrochloride) and 3-[4,5-dimethylthiazol-2-yl]-2,5-diphenyltetrazolium bromide (MTT) were purchased from Sigma Aldrich Co. (St. Louis, MO, USA). Anti-cleaved caspase-3, anti-poly(ADPribose) polymerase (PARP), anti-Bax, anti-Bcl-2 and anti$\beta$-actin antibodies were purchased from Cell Signaling Technology, Inc. (Danvers, MA, USA). All other analytical reagents purchased were of analytical grade.

\section{Cell line and cell cultures}

The human oral cancer cell line derived from Korean, YD-38, was provided by the Korean Cell Line Bank (Seoul, Korea) and cultured as according to the cell culture instructions provided by the Korean Cell Line Bank. Briefly, the YD-38 human oral cancer cells were grown in RPMI 1640 containing 10\% fetal bovine serum (FBS). The cells were maintained as monolayers in plastic culture plates at $37^{\circ} \mathrm{C}$ in a humidified atmosphere containing $5 \%$ $\mathrm{CO}_{2}$ [17].

\section{Cell viability assay}

The cell viability assay (MTT assay) was applied to estimate the effect of metformin on YD-38 oral cancer cell proliferation and performed according to the previously described method with minor modifications $[22,23]$. The cells were plated at a density of $5 \times 10^{3}$ cells/well in 24 well plates and allowed to attach to the well overnight. After overnight growth, the cells were treated with metformin at various concentrations and incubation times. Then, the cells were incubated for a further 4 hours in $20 \mu$ of $5 \mathrm{mg} / \mathrm{ml}$ MTT solution. To dissolve the formazan crystals transformed from MTT, the cells were resuspended in 150 $\mu 1$ dimethyl sulfoxide (DMSO) and the optical density (OD) of the solution was determined using a spectrometer at an incident wavelength of $570 \mathrm{~nm}$. Three separate experiments were performed for each concentration/exposure time combination.

\section{DNA fragmentation analysis}

Following treatment with 0 or $3 \mathrm{mM}$ metformin for 72 hours, approximately $5 \times 10^{6}$ cells were collected and transferred to lysis buffer containing $100 \mathrm{mM} \mathrm{NaCl}, 10 \mathrm{mM}$ EDTA, $300 \mathrm{mM}$ Tris-HCl, pH 7.5, $200 \mathrm{mM}$ sucrose, $0.5 \%$ SDS and $0.5 \mathrm{mg} / \mathrm{ml}$ proteinase $\mathrm{K}$ and incubated at $65^{\circ} \mathrm{C}$. DNA was extracted with an equal volume of phenol/chloroform/isoamylalcohol $(25: 24: 1, \mathrm{v} / \mathrm{v})$ and precipitated with ethanol. The DNA was resuspended in Tris-EDTA buffer, $\mathrm{pH} 8.0$ containing $5 \mu \mathrm{g} / \mathrm{ml}$ DNase-free RNase and incubated at $37^{\circ} \mathrm{C}$ for 1 hour. The DNA was visualized on $2 \%$ agarose gel in the presence of $0.5 \mu \mathrm{g} / \mathrm{ml}$ ethidium bromide.

\section{Immunoblotting}

Immunoblotting was performed according to the previously described method with minor modifications $[23,24]$. Briefly, the YD-38 cells were plated at a density of $5 \times 10^{3}$ cells/well in 24-well plates and allowed to attach to the well overnight. After overnight growth, the cells were treated with 0 or $3 \mathrm{mM}$ metformin for 72 hours. After incubation, the cells were washed twice with ice-cold PBS and lysed using a RIPA buffer for protein extraction according to the manufacturer's instructions. The total protein concentrations were determined using the Bradford Assay (BioRad, Hercules, CA, USA). An equal amount of protein was resolved by $10 \%$ SDS-PAGE and transferred to PVDF membrane for immunoblotting. Membranes were blocked for 2 hours in 5\% non-fat dry milk in TBST. The anticleaved caspase-3 (1:1000 dilution), anti-poly(ADP-ribose) polymerase (PARP) (1:1000 dilution), anti-Bax (1:1000 dilution), anti-Bcl-2 (1:1000 dilution) and anti- $\beta$-actin (1:5000 dilution) antibodies (Cell Signaling Technology, Inc., Danvers, MA, USA) were used as the primary antibody. The immunoactivity was visualized using an Enhanced Chemi Luminescent System (ECL System, Amersham Biosciences, Piscataway, NJ, USA) and a Single Visual Enhancer System (Pierce, Rockford, IL, USA) to magnify the signal.

\section{Data analysis}

All experiments were performed at least three times. The results were presented as the mean \pm SEM. The statistical significance was analyzed by using Student's t-test for two groups and one way analysis of variance for multigroup comparisons. All statistical analyses were performed using SPSS version 12.0 (SPSS Inc., Chicago, IL, USA). Values of $p<0.05$ were considered significant. 


\section{Results}

\section{Cytotoxic effect of metformin in YD-38 cells}

To determine whether metformin affects cell proliferation of YD-38 cells, the cells were treated with metformin at various concentrations for $0-72$ hours, and then the MTT assay was performed. As shown in Fig. 1A, when the YD-38 cells were treated with metformin for $0-72$ hours, metformin inhibited the proliferation of YD-38 cells in a dose-dependent manner, suggesting that metformin induces YD-38 cell death. From 0.1 to $10 \mathrm{mM}$ treatment of metformin, the inhibition of YD-38 cell growth depended on the metformin treatment time (Fig. 1B). The $I C_{50}$ value of metformin on the YD-38 cell viability after a 72 hour treatment was $7.4 \pm 0.9 \mathrm{mM}$ (Table 1).

\section{DNA fragmentation by metformin in YD-38 cells}

Increased cellular apoptosis is only one among several possible mechanisms involved in reduced cell proliferation [25-28]. To determine if apoptosis is indeed the underlying mechanism for the reduced cell proliferation observed, the YD-38 cells treated with metformin were subjected to DNA fragmentation. As shown in Fig. 2, the formation of DNA ladder in the YD-38 cells treated with $3 \mathrm{mM}$ metformin was observed, suggesting that metformin induces apoptotic cell death of YD-38 cells.

\section{Activation of caspase- 3 by metformin}

The level of cleaved caspase- 3 was examined by immu-
Table 1. Anti-proliferative effect of metformin in YD-38 cells

\begin{tabular}{cc}
\hline Time (hours) & $I C_{50}(\mathrm{mM})$ \\
\hline 24 & $\mathrm{ND}$ \\
48 & $\mathrm{ND}$ \\
72 & $7.4 \pm 0.9$ \\
\hline
\end{tabular}

The $I C_{50}$ values represent the mean \pm SEM for three experiments (ND: not detected).

\section{DNA fragmentation}

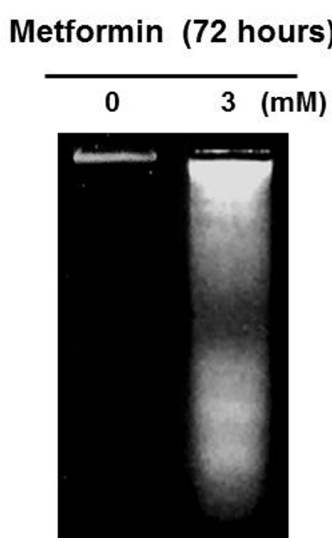

Fig. 2. Fragmentation of internucleosomal DNA by metformin in YD-38 cells. The cells were treated with 0 or $3 \mathrm{mM}$ metformin for 72 hours and nuclear DNA was subjected to agarose gel electrophoresis.

noblotting as caspase-3 is effector caspase of apoptotic cell death [28-31]. Treatment with $3 \mathrm{mM}$ metformin for 72 hours significantly promoted the proteolytic cleavages of procaspase- 3 in the YD-38 cells, with the increases in the amount of cleaved caspase-3 (Fig. 3).

\section{B}

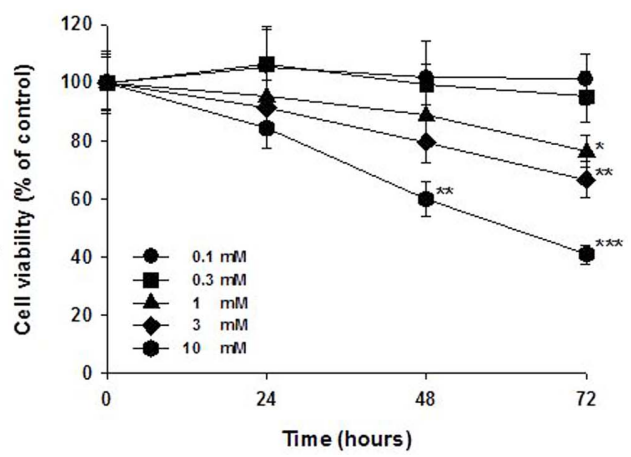

Fig. 1. Concentration- and time-dependent effects of metformin on the cell viability in YD-38 human oral cancer cells. (A) Concentrationdependent effect of metformin on the cell viability in YD-38 cells. The YD-38 cells were treated with various concentrations of metformin or without metformin for 24 (circle), 48 (square) and 72 hours (triangle). (B) Time-dependent effect of metformin on the cell viability in YD38 cells. The YD-38 cells were treated with 0.1 (circle), 0.3 (square), 1 (triangle), 3 (diamond) and $10 \mathrm{mM}$ (hexagon) metformin for 0 - 72 hours. The cell viabilities were determined by the MTT assays. The percentage of cell viability was calculated as a ratio of A570 $0_{\text {nms }}$ of metformin treated cells and untreated control cells. Each data point represents the mean \pm SEM of three experiments. ${ }^{*} P<0.05$ vs. control, ${ }^{* *} P<0.01$ vs. control and ${ }^{* * *} P<0.001$ vs. control (the control cells measured in the absence of metformin). 

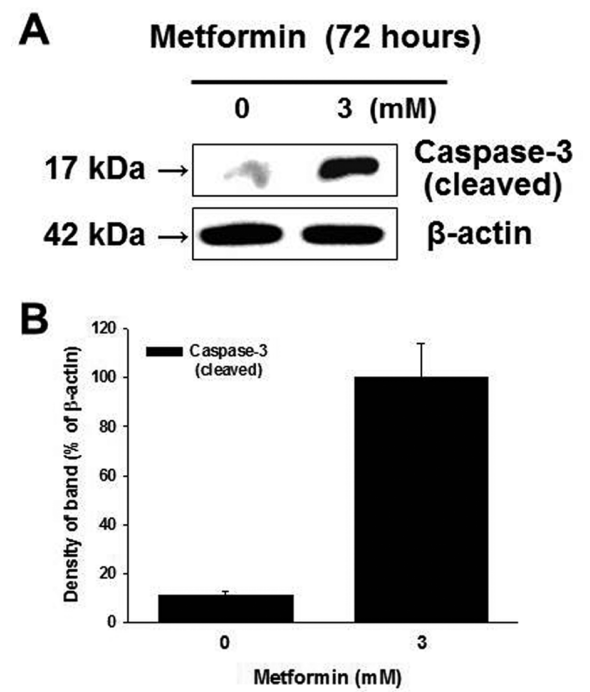

Fig. 3. Proteolytic cleavage of caspase- 3 by metformin treatment in YD-38 cells. (A) Activity of cleaved caspase- 3 by metformin was measured in YD-38 cells. The cells were treated with 0 or $3 \mathrm{mM}$ metformin for 72 hours. The cell lysate was prepared and analyzed by immunoblotting as described in "MATERIALS AND METHODS". (B) Quantitative data for (A) were analyzed by using Imagegauge 3.12 software after $\beta$-actin normalization.
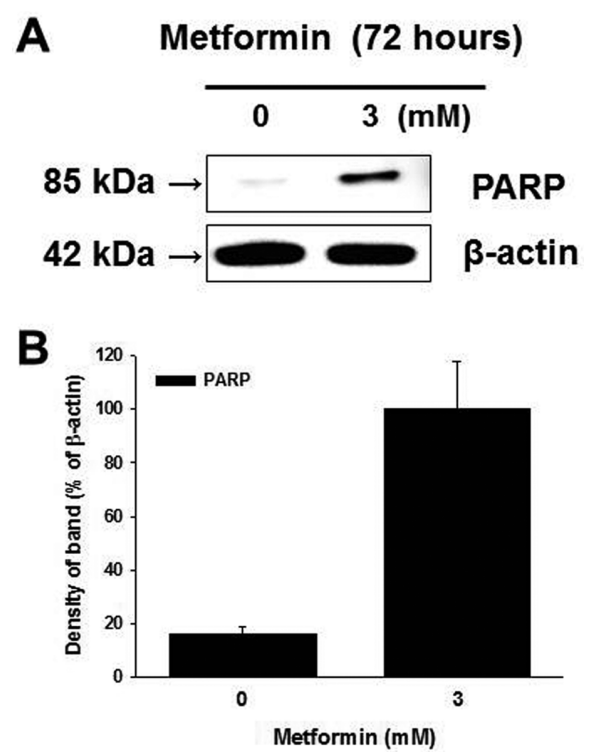

Fig. 4. Activation of cleaved PARP by metformin treatment in YD-38 cells. (A) The activity of cleaved PARP by metformin was measured in YD-38 cells. The YD-38 cells were stimulated with 0 or $3 \mathrm{mM}$ metformin for 72 hours, harvested and lyzed using a cell lysate buffer. (B) Quantitative data for (A) were analyzed by using Imagegauge 3.12 software after $\beta$-actin normalization.

\section{Apoptosis mediated via PARP by metformin}

To determine how metformin induce the extrinsic apoptosis of YD-38 cells, immunoblotting was performed to measure the expression of the PARP at the protein level. As shown in Fig. 4, cleaved-PARP was increased by met-

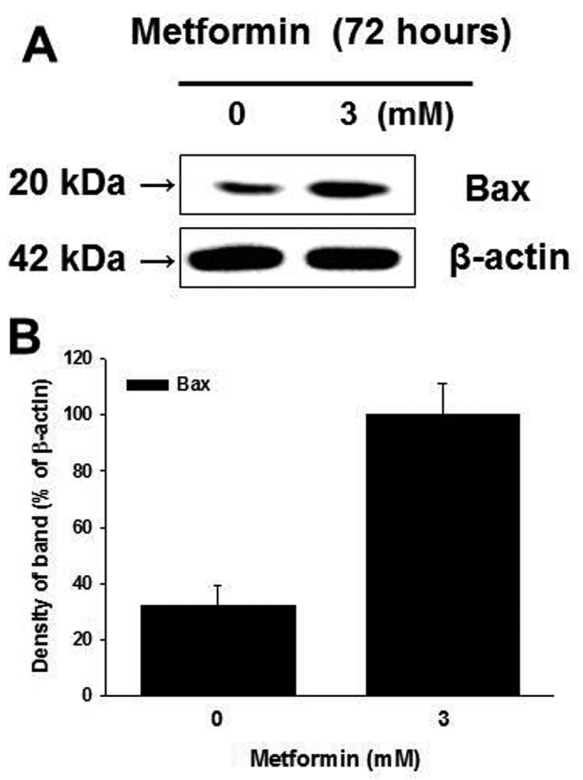

Fig. 5. Regulation of Bax level by metformin treatment in YD-38 cells. (A) The activity of Bax by metformin was measured in YD38 cells. (B) Quantitative data for (A) were analyzed by using Imagegauge 3.12 software after $\beta$-actin normalization.

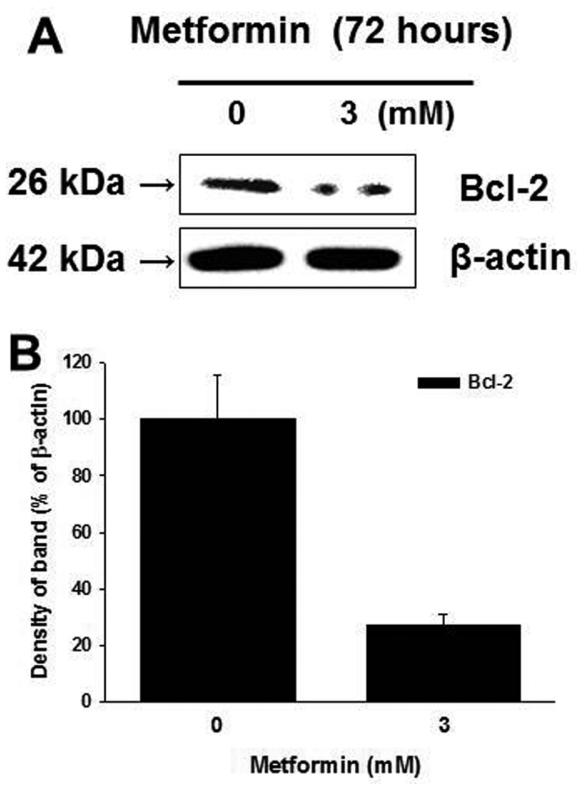

Fig. 6. Regulation of Bcl-2 level by metformin treatment in YD-38 cells. (A) The activity of Bcl-2 by metformin was measured in YD-38 cells. (B) Quantitative data for (A) were analyzed by using Imagegauge 3.12 software after $\beta$-actin normalization.

formin $3 \mathrm{mM}$ compared to the control.

\section{Apoptosis-related signal pathways by metformin}

The levels of proteins that are highly relevant to understanding the apoptotic signaling pathways in YD-38 cells by metformin was measured by immunoblot analysis. The 
treatment of YD-38 cells with metformin increased the level of Bax protein expression (Fig. 5). On the other hand, the level of Bcl-2 protein expression in YD-38 cells stimulated with $3 \mathrm{mM}$ metformin for 72 hours decreased (Fig. 6).

\section{Discussion}

Metformin, derived from French lilac, is an oral hypoglycemic drug that is widely used in the world [1-3]. Moreover, it is known to have anti-cancer effects [11-16]. In addition, type 2 diabetes treated with metformin showed a lower cancer-related mortality and a synergistic therapeutic effect for cancer when combined with chemotherapy [2, 32-34]. Multiple mechanisms are reported to mediate the anti-cancer effects of metformin [35]. However, the metformin effects on oral cancer cells are not clearly established. In this study, therefore, the cytotoxic activity of metformin and the mechanism of cell death exhibited by metformin were examined in YD-38 human oral cancer cells derived from Korean. The present study demonstrated that the metformin can act as an apoptotic inducer in human oral cancer cells.

An MTT assay showed that the metformin inhibited the growth of YD-38 cells in a concentration- and a timedependent manner (Fig. 1). This corresponded with the results of metformin that has anti-cancer effects via the suppression of cancer cell growth in many types of cancer cells [11-16]. These results speculated that metformin has cytotoxicity for oral cancer cells also and potential value for anti-cancer drug discovery.

Apoptosis, which is a major form of programmed cell death, plays an important role in regulating tissue development and homeostasis in eukaryotes [25-27], and the induction of apoptosis in cancer cells is an important indicator of the cancer treatment response [36]. Therefore, the researchers have screened many compounds for their effects on apoptosis $[36,37]$. In the present study, treatment with $3 \mathrm{mM}$ metformin induced the nuclear fragmentation in YD-38 cells (Fig. 2), suggesting apoptotic cell death. These results indicated that metformin inhibits the growth of YD-38 cells by activating cell apoptosis.

The activation of a family of intracellular cysteine proteases, known as caspases, is known to play an important role in the initiation and execution of apoptosis [29, 30]. Among the caspases identified in mammalian cells, caspase-3 can serve as effector caspase of apoptotic cell death [29-31]. Caspase- 3 is synthesized as an inactive proenzyme, which requires proteolytic activation to a cleaved enzyme of size $17 \mathrm{kDa}$ [29-31]. The results of the present study show that low level of cleaved capase- 3 was present in metforminuntreated YD-38 cells, and the amount of cleaved enzyme was increased after metformin treatment in YD-38 cells (Fig. 3). These results suggest that metformin induces apoptotic cell death by the activation of caspase- 3 in YD38 cells.

Apoptosis can occur via a death receptor-mediated extrinsic apoptotic pathway or a mitochondria-mediated intrinsic apoptotic pathway by treatment of anti-cancer agents [38-41]. Also, the cleaved PARP is an important regulatory factor of death receptor-mediated extrinsic apoptotic pathway [36]. In the present study, the expression of the cleaved PARP was up-regulated significantly by metformin in YD-38 cells (Fig. 4). Therefore, these results suggest that metformin-induced apoptosis in YD38 cells is mediated by the death receptor-mediated extrinsic apoptotic pathway via the PARP.

Next, we assessed the effects of metformin on the expression of Bax and Bcl-2 in YD-38 cells. The Bax, pro-apoptotic proteins, and the $\mathrm{Bcl}-2$, anti-apoptotic mitochondrial protein, are important regulators of cytochrome $c$ release from the mitochondria [36, 42, 43]. The Bcl-2 family is localized to the mitochondrial membrane and modulates apoptosis by permeabilizing the mitochondrial membrane, leading to the release of cytochrome $c$ [44]. In the present study, treatment of YD-38 cells with metformin increased the level of Bax (Fig. 5) but decreased the level of Bcl-2 (Fig. 6). The Bax/Bcl-2 ratio is one of the indices of the mitochondria-mediated intrinsic apoptotic pathway [45]. The metformin-induced apoptosis appears to involve $\mathrm{Bax} / \mathrm{Bcl}-2$ signal transduction since metformin increased this ratio in YD-38 cells. Therefore, metformin is suggested to induce apoptosis in YD-38 cells involving the mitochondrial- and death receptor-signal transduction pathways. On the other hand, the mechanisms of apoptosis induced by metformin in YD-38 cells are not fully understood. Further studies are required to examine the precise cellular and molecular mechanisms of apoptosis induced by metformin.

In conclusion, these in vitro results suggest that the metformin inhibits cell proliferation and induces apoptotic cell death in YD-38 human oral cancer cells derived from Korean through both the death receptor-mediated extrinsic 
apoptotic pathway and the mitochondria-mediated intrinsic apoptotic pathway. Moreover, these results suggest that the metformin may provide a strategy for preventing and treating oral cancer and more research is needed to explore the molecular mechanisms.

\section{Acknowledgements}

This study was supported by research fund from Chosun University, 2017.

\section{Conflict of Interest}

The authors declare that they have no competing interests.

\section{ORCID}

$\begin{array}{ll}\text { Dong Kuk Seo } & 0000-0002-1007-894 X \\ \text { Su-Gwan Kim } & 000-0002-0424-9984 \\ \text { Dae-San Go } & 0000-0002-5675-6195 \\ \text { Chun Sung Kim } & 0000-0001-8612-3420 \\ \text { Sun-Kyoung Yu } & 0000-0003-0801-1663 \\ \text { Do Kyung Kim } & 0000-0001-6254-946 X\end{array}$

\section{References}

1. Rêgo DF, Pavan LM, Elias ST, De Luca Canto G, Guerra EN. Effects of metformin on head and neck cancer: a systematic review. Oral Oncol 2015;51:416-422. doi: 10.1016/j.oraloncology.2015.01.007.

2. Jiralerspong S, Palla SL, Giordano SH, Meric-Bernstam F, Liedtke C, Barnett CM, Hsu L, Hung MC, Hortobagyi GN, Gonzalez-Angulo AM. Metformin and pathologic complete responses to neoadjuvant chemotherapy in diabetic patients with breast cancer. J Clin Oncol 2009; 27:3297-3302. doi: 10.1200/JCO.2009.19.6410.

3. Memmott RM, Mercado JR, Maier CR, Kawabata S, Fox SD, Dennis PA. Metformin prevents tobacco carcinogen-induced lung tumorigenesis. Cancer Prev Res (Phila) 2010;3:1066-1076. doi: 10.1158/1940-6207.CAPR-10-0055.

4. Jang WG, Kim EJ, Lee KN, Son HJ, Koh JT. AMP-activated protein kinase (AMPK) positively regulates osteoblast differentiation via induction of Dlx5-dependent Runx2 expression in MC3T3E1 cells. Biochem Biophys Res Commun 2011;404:1004-1009. doi: 10.1016/j.bbrc.2010.
12.099 .

5. Jang WG, Kim EJ, Bae IH, Lee KN, Kim YD, Kim DK, Kim SH, Lee CH, Franceschi RT, Choi HS, Koh JT. Metformin induces osteoblast differentiation via orphan nuclear receptor SHP-mediated transactivation of Runx2. Bone 2011;48:885-893. doi: 10.1016/j.bone.2010.12.003.

6. Viollet B, Guigas B, Sanz Garcia N, Leclerc J, Foretz M, Andreelli F. Cellular and molecular mechanisms of metformin: an overview. Clin Sci (Lond) 2012;122:253-270. doi: 10.1042/CS20110386.

7. Pernicova I, Korbonits M. Metformin-mode of action and clinical implications for diabetes and cancer. Nat Rev Endocrinol 2014;10:143-156. doi: 10.1038/nrendo. 2013.256.

8. El-Mir MY, Nogueira V, Fontaine E, Avéret N, Rigoulet M, Leverve X. Dimethylbiguanide inhibits cell respiration via an indirect effect targeted on the respiratory chain complex I. J Biol Chem 2000;275:223-228. doi: 10.1074/jbc.275.1.223.

9. Lord JM, Flight IH, Norman RJ. Metformin in polycystic ovary syndrome: systematic review and meta-analysis. BMJ 2003;327:951-953. doi: http://dx.doi.org/10.1136/ bmj.327.7421.951.

10. Marchesini G, Brizi M, Bianchi G, Tomassetti S, Zoli M, Melchionda N. Metformin in non-alcoholic steatohepatitis. Lancet 2001;358:893-894. doi: 10.1016/S0140-6736 (01)06042-1.

11. Jeong YK, Kim MS, Lee JY, Kim EH, Ha H. Metformin radiosensitizes $\mathrm{p} 53$-deficient colorectal cancer cells through induction of G2/M arrest and inhibition of DNA repair proteins. PLoS One 2015;10:e0143596. doi: 10.1371/journal.pone.0143596.

12. Yasmeen A, Beauchamp MC, Piura E, Segal E, Pollak $\mathrm{M}$, Gotlieb WH. Induction of apoptosis by metformin in epithelial ovarian cancer: involvement of the Bcl-2 family proteins. Gynecol Oncol 2011;121:492-498. doi: 10.1016/j. ygyno.2011.02.021.

13. Shank JJ, Yang K, Ghannam J, Cabrera L, Johnston CJ, Reynolds RK, Buckanovich RJ. Metformin targets ovarian cancer stem cells in vitro and in vivo. Gynecol Oncol 2012;127:390-397. doi: 10.1016/j.ygyno.2012.07.115.

14. Han D, Li SJ, Zhu YT, Liu L, Li MX. LKB1/AMPK/ mTOR signaling pathway in non-small-cell lung cancer. Asian Pac J Cancer Prev 2013;14:4033-4039. doi: http:/ /dx.doi.org/10.7314/APJCP.2013.14.7.4033.

15. Soranna D, Scotti L, Zambon A, Bosetti C, Grassi G, Catapano A, La Vecchia C, Mancia G, Corrao G. Cancer risk associated with use of metformin and sulfonylurea in type 2 diabetes: a meta-analysis. Oncologist 2012;17:813822. doi: 10.1634/theoncologist.2011-0462.

16. Hwang IC, Park SM, Shin D, Ahn HY, Rieken M, Shariat SF. Metformin association with lower prostate cancer recurrence in type 2 diabetes: a systematic review and 
meta-analysis. Asian Pac J Cancer Prev 2015;16:595-600. doi: 10.7314/APJCP.2015.16.2.595.

17. Yun DW, Lee SA, Park MG, Kim JS, Yu SK, Park MR, Kim SG, Oh JS, Kim CS, Kim HJ, Kim JS, Chun HS, Kanai Y, Endou H, Wempe MF, Kim DK. JPH203, an Ltype amino acid transporter 1-selective compound, induces apoptosis of YD-38 human oral cancer cells. J Pharmacol Sci 2014;124:208-217. doi: 10.1254/jphs.13154FP.

18. Notani PN. Epidemiology and prevention of head and neck cancer: a global view. In: Saranath D, editor. Contemporary Issues in Oral Cancer. New Delhi: Oxford University Press; 2000. p.1-29.

19. Moreno-Lopez LA, Esparza-Gomez GC, Gonzalez-Navarro A, Cerero-Lapiedra R, Gonzalez-Hernandez MJ, Dominguez-Rojas V. Risk of oral cancer associated with tobacco smoking, alcohol consumption and oral hygiene: a casecontrol study in Madrid, Spain. Oral Oncol 2000;36:170174. doi: 10.1016/S1368-8375(99)00084-6.

20. Ellis GL, Auclair PL, Gnepp DR. Surgical pathology of the salivary glands. In: Auclair PL, Ellis GL, editors. Primary squamous cell carcinoma. Philadelphia: W. B. Saunders Company; 1991. p.369-378.

21. Kim JS, Oh D, Yim MJ, Park JJ, Kang KR, Cho IA, Moon SM, Oh JS, You JS, Kim CS, Kim DK, Lee SY, Lee GJ, Im HJ, Kim SG. Berberine induces FasL-related apoptosis through p38 activation in KB human oral cancer cells. Oncol Rep 2015;33:1775-1782. doi: 10.3892/ or.2015.3768.

22. Shin WC, Kim CS, Kim HJ, Lee MH, Kim HR, Kim DK. Growth inhibition of human head and neck squamous cell carcinomas by Angelica decursiva extracts. Int J Oral Biol 2010;35:153-158.

23. Kim SY, Kim SG, JS Oh, Cha YJ, Moon YH, Kim DK. Anticancer effects of quercetin on KB human oral cancer cells. Oral Biol Res 2012;36:113-122.

24. Park BS, Kim JS, Go DS, Kim SG, Oh JS, Seo YS, Kim CS, Kim DK. Cell growth inhibition by bavachin in KB human oral cancer cells. Oral Biol Res 2015;39:39-46.

25. Green DR, Reed JC. Mitochondria and apoptosis. Science 1998;281:1308-1312. doi: 10.1126/science.281.5381. 1309.

26. Hengartner MO. The biochemistry of apoptosis. Nature 2000;407:770-776. doi: 10.1038/35037710.

27. Kaufmann SH, Hengartner MO. Programmed cell death: alive and well in the new millennium. Trends Cell Biol 2001;11:526-534. doi: 10.1016/S0962-8924(01)02173-0.

28. Hu W, Kavanagh JJ. Anticancer therapy targeting the apoptotic pathway. Lancet Oncol 2003;4:721-729. doi: 10.1016/S1470-2045(03)01277-4.

29. Cohen GM. Caspases: the executioners of apoptosis. Biochem J 1997;326:1-16. doi: 10.1042/bj3260001.

30. Datta R, Kojima H, Yoshida K, Kufe D. Caspase-3mediated cleavage of protein kinase $\mathrm{C}$ theta in induction of apoptosis. J Biol Chem 1997;272:20317-20320. doi: 10.1074/jbc.272.33.20317.

31. Liu X, Zou H, Slaughter C, Wang X. DFF, a heterodimeric protein that functions downstream of caspase-3 to trigger DNA fragmentation during apoptosis. Cell 1997; 89:175-184. doi: 10.1016/S0092-8674(00)80197-X.

32. Landman GW, Kleefstra N, van Hateren KJ, Groenier KH, Gans RO, Bilo HJ. Metformin associated with lower cancer mortality in type 2 diabetes: ZODIAC-16. Diabetes Care 2010;33:322-326. doi: 10.2337/dc09-1380.

33. Sadeghi N, Abbruzzese JL, Yeung SC, Hassan M, Li D. Metformin use is associated with better survival of diabetic patients with pancreatic cancer. Clin Cancer Res 2012;18:2905-2912. doi: 10.1158/1078-0432.CCR-11-2994.

34. Lee JH, Kim TI, Jeon SM, Hong SP, Cheon JH, Kim WH. The effects of metformin on the survival of colorectal cancer patients with diabetes mellitus. Int J Cancer 2012;131:752-759. doi: 10.1002/ijc.26421.

35. Shackelford DB, Shaw RJ. The LKB1-AMPK pathway: metabolism and growth control in tumour suppression. Nat Rev Cancer 2009;9:563-575. doi: 10.1038/nrc2676.

36. Yang SJ, Lee SA, Park MG, Kim JS, Yu SK, Kim CS, Kim JS, Kim SG, Oh JS, Kim HJ, Chun HS, Kim YH, Kim DK. Induction of apoptosis by diphenyldifluoroketone in osteogenic sarcoma cells is associated with activation of caspases. Oncol Rep 2014;31:2286-2292. doi: 10.3892/or.2014.3066.

37. Mukherjee AK, Basu S, Sarkar N, Ghosh AC. Advances in cancer therapy with plant based natural products. Curr Med Chem 2001;8:1467-1486. doi: 10.2174/0929867013372094.

38. Kaufmann SH, Earnshaw WC. Induction of apoptosis by cancer chemotherapy. Exp Cell Res 2000;256:42-49. doi: 10.1006/excr.2000.4838.

39. Reed JC. Apoptosis-regulating proteins as targets for drug discovery. Trends Mol Med 2001;7:314-319. doi: 10.1016/S1471-4914(01)02026-3.

40. Druesne-Pecollo N, Latino-Martel P, Norat T, Barrandon E, Bertrais S, Galan P, Hercberg S. Beta-carotene supplementation and cancer risk: a systematic review and metaanalysis of randomized controlled trials. Int J Cancer 2010;127:172-184. doi: 10.1002/ijc.25008.

41. Wang SK, Yang L, Wang TT, Huang GL, Yang LG, Sun GJ. Inhibition of proliferation and induction of apoptosis by the combination of metformin and 1,25-dihydroxyvitamin D3 in human esophageal cancer EC9706 cells. Asian Pac J Cancer Prev 2012;13:6327-6332. doi: 10.7314/APJCP.2012.13. 12.6327.

42. Kluck RM, Bossy-Wetzel E, Green DR, Newmeyer DD. The release of cytochrome $\mathrm{c}$ from mitochondria: a primary site for Bcl-2 regulation of apoptosis. Science 1997;275:1132-1136. doi: 10.1126/science.275.5303.1132.

43. Kluck RM, Esposti MD, Perkins G, Renken C, Kuwana T, Bossy-Wetzel E, Goldberg M, Allen T, Barber MJ, 
Dong Kuk Seo et al.

Green DR, Newmeyer DD. The pro-apoptotic proteins, Bid and Bax, cause a limited permeabilization of the mitochondrial outer membrane that is enhanced by cytosol. J Cell Biol 1999;147:809-822. doi: 10.1083/jcb.147. 4.809 .

44. Yu CS, Huang AC, Lai KC, Huang YP, Lin MW, Yang JS, Chung JG. Diallyl trisulfide induces apoptosis in human primary colorectal cancer cells. Oncol Rep 2012;28:949-954. doi: 10.3892/or.2012.1882.

45. Oltvai ZN, Milliman CL, Korsmeyer SJ. Bcl-2 heterodimerizes in vivo with a conserved homolog, Bax, that accelerates programmed cell death. Cell 1993;74:609619. doi: 10.1016/0092-8674(93)90509-O. 